\title{
A Quiet Revolution: The Exclusivity of Exclusive Economic Zones
}

\author{
Margaret A Young
}

\section{Introduction}

The allocation of sovereignty and sovereign rights is international law's driving force. In lawmaking and dispute resolution, international law not only distributes resources, but shapes power, knowledge and ideas. This is an ongoing feature of treaty negotiations, both of multilateral packages, such as an agreement on marine biological diversity in the high seas, ${ }^{2}$ and of smaller, regional endeavours, such as a Pacific-based trade agreement. ${ }^{3}$ It is also present in the resolution of disputes by international courts and tribunals, of which the South China Sea Award is a leading example. ${ }^{4}$ When pronouncements are made on which countries can access which markets or jurisdictional zones (and which tribunals can compulsorily hear claims arising from those rights), the implications can be revolutionary.

\footnotetext{
1 With thanks for helpful comments to Katharine Young, Camille Goodman and the participants at The Australian National University symposium, especially Hilary Charlesworth and Kim Rubenstein. 2 See, eg, negotiations for an anticipated binding instrument to protect marine biological diversity in areas outside national jurisdiction: International Legally Binding Instrument Under the United Nations Convention on the Law of the Sea on the Conservation and Sustainable Use of Marine Biological Diversity of Areas Beyond National Jurisdiction, GA Res 72/249, $72^{\text {nd }}$ sess, Agenda Item 77, UN Doc A/RES/72/249 (adopted 24 December 2017); the fourth and final session of the Intergovernmental Conference has been postponed by decision 74/543 of 11 March 2020.

3 Comprehensive and Progressive Agreement for Trans-Pacific Partnership (CPTPP), signed by 11 countries, 8 March 2018, [2018] ATS 23 (entered into force 30 December 2018).

4 In the Matter of the South China Sea Arbitration before an Arbitral Tribunal Constituted under Annex VII to the 1982 United Nations Convention on the Law of the Sea (Philippines $v$ China) (Award) (Permanent Court of Arbitration, Case No 2013-19, 12 July 2016) ('South China Sea Award), available at: <https://pca-cpa.org/en/cases/7/>.
} 
In 1987, Deborah Cass foresaw a quiet revolution in the developments of maritime zones ${ }^{5}$ within the recently concluded United Nations Convention on the Law of the Sea (UNCLOS). ${ }^{6}$ Hers was an early intervention when UNCLOS was still yet to enter into force, but when countries around the world had already devoted nine years of their time and international advocacy in order to agree on a 'package deal' for the oceans. The UNCLOS negotiations - a third in a series of historic negotiations and known by the acronym UNCLOS III - took place during the late 1970s and 1980s, when decolonised developing countries sought to challenge historic arrangements which had allowed strong maritime powers to exploit the distant waters surrounding weaker states. Concepts such as 'permanent sovereignty over natural resources', 'preferential rights' and the 'common heritage of mankind' were debated. An exclusive economic zone, or EEZ, was the newly recognised zone beyond and adjacent to the territorial sea, extending 200 nautical miles from a coastal state. UNCLOS entrenched the sovereign rights of those coastal states to the resources of the zone, thus limiting the size and concept of traditional notions of freedom of fishing on the high seas. ${ }^{7}$

Deborah Cass's analysis - her first legal publication in a series of engagements with matters of international and constitutional law heralded an ongoing intuition for issues of disciplinary significance. Fisheries is the international law problem par excellence: one of the earliest examples of interstate cooperation seemingly driven by material facts, such as migratory species crossing borders of states, but also infused with ephemeral concepts like justice and fairness. The earliest international law texts are devoted to it, ${ }^{8}$ and the ministries of foreign affairs of most states remain occupied with it. ${ }^{9}$ Understanding the patterns of behaviour, reasons for cooperation and precursors to normative development in fisheries allows one to make sense of international law's subsequent response to concerns that only latterly have been conceived as global.

5 Deborah Cass, 'The Quiet Revolution: The Development of the Exclusive Economic Zone and Implications for Foreign Fishing Access in the Pacific' (1987) 16 Melbourne University Law Review 83.

6 United Nations Convention on the Law of the Sea, opened for signature 4 June 1992, 1833 UNTS 396 (entered into force 16 November 1994) ('UNCLOS').

7 UNCLOS (n 6) pt V ('Exclusive Economic Zone').

8 David Armitage, The Free Sea: With William Welwod's Critique \& Grotius's Reply (Liberty Fund Inc, 2004), which includes Hugo Grotius's Mare Liberum, first published 1609.

9 One could cite current examples from all regions, from the skirmishes between French and British scallop fishermen, the reluctance of distant water fishing nations to agree to conservation and management measures in the Pacific islands, and the ongoing fisheries disputes in the South China Sea. 
Indeed, I suspect I may share at least one affinity with Deborah Cass: ${ }^{10}$ a professional conviction that some of the greatest social and legal problems of our time can be understood through the lens of fisheries. Even though I met her but a few times, I am confident that Deborah Cass would be in complete agreement with that conviction, and would similarly enjoy the incredulous reactions of others to it.

This chapter is structured in three parts. First, I draw attention to the high political and ideological stakes in UNCLOS's recognition of maritime zones. Deborah Cass was interested in the geopolitics behind the changing economic relationships between the Pacific island states and the distant water fishing nations such as the Soviet Union and the US. The first part of this chapter reflects upon her arguments in the context of a very different environment from the Cold War-inspired era in which she wrote. In the second part, I move to some relevant provisions of UNCLOS relating to the EEZ, particularly art 56's provision for rights, jurisdiction and duties of the coastal state in the EEZ. I engage with Deborah Cass's hypothesis that art 56 provided for full discretion for coastal states in denying access to foreign fishing nations, comparing this analysis with later interpretations from international tribunals such as the International Tribunal for the Law of the Sea (ITLOS) and ad hoc tribunals. I show that though her fishery study was extremely perceptive, it did not account for some emerging issues relating to unfettered coastal state discretion. These issues are examined in the third part of the chapter, which examines the need for coastal states to cooperate and give 'due regard' to others while practicing 'due diligence' with respect to the resources within the EEZ.

\section{The High Stakes of the Maritime Zones}

The geopolitical and ideological aspects of the newly formed EEZs have changed drastically since Deborah Cass's writing, but the high stakes behind the allocation of jurisdictional zones in UNCLOS have not diminished. Indeed, with the ecological pressures on fishing now leading to recommendations to close the remaining areas outside of the EEZs

10 Another might be a recently discovered intercultural appreciation for a hand-written family recipe for borscht; see Deborah's creative writing piece, Deborah Cass, 'Her Beauty as a Sword' (2011) 10 Etchings 5-12. 
(the high seas) to extractive fishing as a precautionary measure, ${ }^{11}$ the stakes have risen even higher. Deborah Cass's insights foreshadow the struggle for power and legitimacy that currently dominates the law of the sea, especially in the Pacific. Her reflections on the ability of foreign fishing nations to access the EEZs of coastal states in the Pacific combined technical analysis of state practice and custom as well as broader reflections on geopolitical and ideological implications. She went further than interpretation of the treaty text and delved into media interviews and ministerial statements, a method that provided excellent sources for her perspectives on contemporary ideas about 'creeping jurisdiction' and the global economic order. This part adopts a similar method to re-examine UNCLOS's imposition of law amid changing patterns of sovereign power.

\section{Curbing the Distant Water Fishing Nations}

UNCLOS signalled a major change in fishing access, because the concept of the EEZ allowed smaller, less sophisticated states to deny access to their fishing zones to the larger and exploitative 'distant water fishing nations'. ${ }^{12}$ Those large maritime nations had been sailing the world for centuries to plunder living resources in faraway places. The two distant water fishing nations that possessed the largest fleets, the Soviet Union and Japan, sought a preservation of the status quo at UNCLOS III, with the granting of mere 'preferential rights' to the coastal states. ${ }^{13}$ Instead, the finalised EEZ regime was more closely aligned with the demands of Latin American and African states, who had been seeking greater control over coastal resources even before UNCLOS III, especially in the face of the growing

11 U Rashid Sumaila et al, 'Fisheries Subsidies and Potential Catch Loss in SIDS Exclusive Economic Zones: Food Security Implications (2013) 18(4) Environmental and Development Economics 427, doi.org/10.1017/s1355770x13000156; see also Cassandra M Brooks et al, 'Challenging the “Right to Fish” in a Fast-Changing Ocean' (2014) 33 Stanford Environmental Law Journal 289.

12 Although this term dominates the secondary literature, UNCLOS refers instead to 'States whose nationals have habitually fished in the zone or which have made substantial efforts in research and identification of stocks': arts 62, 69. Part V of UNCLOS also refers variously to 'developed landlocked States', 'geographically disadvantaged States' and 'developing States'. In negotiations, states had used various language, for example the Chinese representative referred to ' $t$ ] he super-Powers [that] had for years wantonly plundered the offshore resources of developing coastal States, thereby seriously damaging their interests': Summary Records of Meetings of the Second Committee, 24th mtg, UN Doc A/CONF.62/C.2/SR.24 (1 August 1974) [2]; Official Records of the Third United Nations Conference on the Law of the Sea, Volume II (Summary Records of Meetings of the First, Second and Third Committees, Second Session) 187, <https://legal.un.org/diplomaticconferences/1973_los/vol2.shtml>, cited in South China Sea Award (n 4) para 251.

13 South China Sea Award (n 4) [248]-[254]. 
technological capacity of the distant water fishing nations. ${ }^{14}$ It has been commented that 'the evolution of the exclusive economic zone concept took place in the developing world'. ${ }^{15}$ By recognising sovereign rights of coastal states, UNCLOS shifted the resource base and opportunities of those coastal nations; now, 35 per cent of the oceans and 75-80 per cent of fish stock would be subject to EEZ jurisdiction. ${ }^{16}$

But Deborah Cass was not content to mark this as a simple shift in resource allocation. She argued that the 'dramatic' jurisdictional change 'has brought with it the fear of a revolution of a more sweeping kind'. ${ }^{17}$ The emergence of the EEZ doctrine and its associated increase in economic autonomy was a sign for Deborah Cass of more fundamental transformations. The Pacific island state of Kiribati had just used its coastal jurisdiction to negotiate access rights for fishing nations to its EEZ: instead of allowing the US boats that had traditionally fished in the area to procure access for a fee, Kiribati sold the rights to the highest bidder, which happened to be the Soviets. Quoting a news report headed 'Soviets Get New Pacific Toehold', Deborah Cass argued that 'fishing rights have suddenly become the battleground for global ideological conflict'. ${ }^{18}$ In references to Australian parliamentary debates and diplomatic correspondence, she showed that the link between fishing, economic changes and national security was being made in Australia and abroad. The Pacific states were seen by Australia's Secretary of the Department of Foreign Affairs as 'inevitably open to exploitation or infiltration from outside'. ${ }^{19}$

\section{Global Ideological Conflict}

In tracing the shifts in fishing rights represented by UNCLOS's EEZ regime to global ideological conflict during the last years of the Cold War, Deborah Cass demonstrated how international law is shaped by and generates power relations which, for some proponents, are used in ideological narratives. Her work was referenced in David Caron's

\footnotetext{
14 Ibid.

15 Satya Nandan, 'The Exclusive Economic Zone: A Historic Perspective' in Food and Agriculture Organization (ed), The Law and the Sea: Essays in Memory of Jean Carroz (Food and Agriculture Organization, 1987) <http://www.fao.org/docrep/s5280T/s5280t00.htm>.

16 MH Belsky, 'Management of Large Marine Ecosystems: Developing a New Rule of Customary International Law' (1985) 22 San Diego Law Review 733, 759, cited in Cass 'The Quiet Revolution' (n 5) 83 .

17 Cass, 'The Quiet Revolution' (n 5) 83.

18 Ibid.

19 Ibid 101.
} 
examination of the US's use of sanctions as an instrument of foreign policy, which considered historic denials of access for fishing privileges, including to the Soviet Union in the late 1970s and Poland in the early 1980 s, as well as a number of whaling nations. ${ }^{20}$

Similar issues were relevant to the negotiations of other parts of UNCLOS, particularly the negotiations over rights to the deep seabed, and the contestation over the concept of 'common heritage of mankind', which had been proposed by Maltese diplomat, Arvid Pardo, to the United Nations General Assembly in 1967, and which promised to ensure equitable sharing of projected seabed mining. ${ }^{21}$ By instituting a regime in which 'the Area and its resources are the common heritage of mankind'22 (Part XI), the Convention entrenched universal aspirations observed by Philip Allott to be 'the new wine of communitarianism spilling over from the old bottle of legal formalism'. ${ }^{23}$ It was this allocation of rights within the deep seabed mining regime - and not UNCLOS's provisions regarding highly migratory species, as Deborah Cass argued ${ }^{24}$ - that is said to have proved the most significant impediment to ratification of the UNCLOS by the US. ${ }^{25}$

Of course, given the trajectory of the Cold War, the framing of issues of access to fishing resources as a contestation between capitalism and communism did not last long. The Pacific islands built their bargaining power against distant water fishing nations within a number of regional cooperatives. ${ }^{26}$ Soon after the publication of Deborah Cass's article,

20 David D Caron, 'International Sanctions, Ocean Management, and the Law of the Sea: A Study of Denial of Access to Fisheries' (1989) 16 Ecology Law Quarterly 311.

21 Arvid Pardo, 'Who Will Control the Seabed?' (1968-1969) 47 Foreign Affairs 123; Arvid Pardo, 'Address to the American Society of International Law' (1968) 62 ASIL Proceedings 216; Arvid Pardo, 'Sovereignty under the Sea' (1968) 58 Commonwealth Journal of International Affairs 341; see generally Surabhi Ranganathan, 'Global Commons' (2016) 27 European Journal of International Law 693.

$22 \mathrm{UNCLOS} \mathrm{(n} \mathrm{6)} \mathrm{art} 136$.

23 Philip Allott, 'Mare Nostrum: A New International Law of the Sea' (1992) 86 American Journal of International Law 764, 785, doi.org/10.1017/s0002930000010927.

24 Cass, 'The Quiet Revolution' (n 5) 94.

25 John R Stevenson and Bernard H Oxman, 'The Future of the United Nations Convention on the Law of the Sea' (1994) 88 American Journal of International Law 477, 477, doi.org/10.2307/2203716.

26 The Forum Fisheries Agency was first established in 1979: South Pacific Forum Fisheries Agency Convention, opened for signature on 10 July 1979, 1579 UNTS 315 (entered into force 9 August 1979). Eight of the members of this Forum with adjoining exclusive economic zones formed a subregional group known as Parties to the Nauru Agreement (PNA) in 1982: Nauru Agreement Concerning Cooperation in the Management of Fisheries of Common Interest, opened for signature 11 February 1982 (entered into force 4 December 1982) <http://www.pnatuna.com/sites/default/files/Nauru\%20Agreement_0.pdf>. The members of the PNA are the Federated States of Micronesia, Kiribati, Marshall Islands, Nauru, Palau, Papua New Guinea, Solomon Islands and Tuvalu. 
US fishing boats returned to the region. ${ }^{27}$ The controversial issue of highly migratory species in the western and central Pacific Ocean was directly addressed by the establishment of a new commission. ${ }^{28}$ The imperative of coastal states and other states to cooperate within this commission was given impetus by the 1994 Fish Stocks Agreement, which the US was one of the first countries to ratify. ${ }^{29}$ Pacific states have sought a range of enforcement measures to assist in policing their areas and ensuring they receive a commercial return from the foreign states to which they have permitted access. ${ }^{30}$ Some have even closed their fishing zones due to environmental concerns, ${ }^{31}$ amid a more general awareness that agreed access rights to EEZs can be exploitative and unsustainable. ${ }^{32}$

These developments were not relevant solely to the law of the sea. Other treaty regimes recorded agreements and fostered expectations, some of which diverged from UNCLOS III. For many developing countries, a legal interest in access to fishing zones was overshadowed by a legal interest in access to fishing markets: developing countries challenged the legal compatibility of attempts by developed countries to restrict

27 Cass, 'The Quiet Revolution' (n 5) 102.

28 Convention on the Conservation and Management of Highly Migratory Fish Stocks in the Central and Western Pacific Ocean, opened for signature 5 September 2000, 2275 UNTS 43 (entered into force 19 June 2004), <https://www.wcpfc.int/about-wcpfc>, establishing the Western and Central Pacific Fisheries Commission. Current members of the Commission are Australia, China, Canada, Cook Islands, European Union, Federated States of Micronesia, Fiji, France, Indonesia, Japan, Kiribati, Republic of Korea, Republic of Marshall Islands, Nauru, New Zealand, Niue, Palau, Papua New Guinea, Philippines, Samoa, Solomon Islands, Chinese Taipei, Tonga, Tuvalu, United States of America and Vanuatu.

29 United Nations Agreement for the Implementation of the Provisions of the United Nations Convention on the Law of the Sea of 10 December 1982 relating to the Conservation and Management of Straddling Fish Stocks and Highly Migratory Fish Stocks, opened for signature 4 December 1995, 2167 UNTS 88 (entered into force 11 December 2001) ('Fish Stocks Agreement'). The US was the third state to ratify the Fish Stocks Agreement (on 24 August 1996). See further Tore Henriksen and Alf Håkon Hoel, 'Determining Allocation: From Paper to Practice in the Distribution of Fishing Rights Between Countries Determining Allocation' (2011) 42 Ocean Development \& International Law 66, doi.org/ $10.1080 / 00908320.2011 .542106$.

30 See generally Camille Goodman, 'The Cooperative Use of Coastal State Jurisdiction with Respect to Highly Migratory Stocks: Insights from the Western and Central Pacific Region' in Lawrence Martin, Constantinos Salonidis and Christina Hioureas (eds), Natural Resources and the Law of the Sea: Exploration, Allocation, Exploitation of Natural Resources in Areas under National Jurisdiction and Beyond (JurisNet, 2017) 215.

31 For a list of closed areas within the jurisdiction of countries of the Pacific Islands Forum Fisheries Agency, see 'PIP Closed Areas', Pacific Islands Forum Fisheries Agency (FFA) (Web Page, 23 November 2016) <https://www.ffa.int/us_mtreaty_closed_areas>.

32 For one example on access agreements with the EU leading to adverse effects on the sustainability of Senegal's coastal fisheries, see Emma Witbooi, 'The Infusion of Sustainability into Bilateral Fisheries Agreements with Developing Countries: The European Union Example' (2008) 32 Marine Policy 669, 674, doi.org/10.1016/j.marpol.2007.11.008. 
access to their markets on environmental grounds. ${ }^{33}$ Part XI on the deep seabed regime was renegotiated; the resulting new agreement of $1994^{34}$ was said to represent a 'mutilated' regime..$^{35}$ Overcapacity of the entire fishing fleet was increasingly recognised as a problem for conservation and management. Alongside the subsidy programs of distant water fishing nations, who had built up their fleets in order to enhance their competitive advantages, coastal states began to allocate more resources to their fishing industries in order to better exploit their expanded EEZ rights. ${ }^{36}$ Subsidies of states to their fishing fleets became a focus for reform at the World Trade Organization (WTO) in 2001. ${ }^{37}$ Members agreed to seek to clarify disciplines on fisheries subsidies for both economic and ecological objectives. ${ }^{38}$ Meanwhile, for many developing countries the economic gains of an increased EEZ have been gouged by rampant illegal, unreported and unregulated (IUU) fishing. ${ }^{39}$ As well as threatening revenues of coastal states - estimated at over US $\$ 600$ million annually for the Pacific island states alone ${ }^{40}$ - IUU fishing has caused social dislocation and environmental degradation. ${ }^{41}$ The allocation of resources to enhance capacity, which is planned by the state, driven by private capital or sourced from a combination of both, shows that jurisdictional zones under the law of the sea are not the only influence on practices of exploitation and overexploitation.

33 See also Margaret A Young, Trading Fish, Saving Fish: The Interaction between Regimes in International Law (Cambridge University Press, 2011), doi.org/10.1017/s2047102512000167.

34 Agreement Relating to the Implementation of Part XI of the Convention of 10 December 1982, 48 ${ }^{\text {th }}$ sess, Agenda Item 36, UN Doc A/RES/48/263 (entered into force 28 July 1966).

35 As Ranganathan has shown, the strong language came from RP Anand, an earlier contributor to Third World approaches to international law in his Studies in International Law and History: An Asian Perspective (Springer, 2004) 188, cited in Ranganathan (n 21) 712.

36 J Samuel Barkin and Elizabeth R DeSombre, Saving Global Fisheries: Reducing Fishing Capacity to Promote Sustainability (MIT Press, 2013) 106-7, doi.org/10.1162/glep_r_00233.

37 See Doha Ministerial Declaration, WTO Doc WT/MIN(01)/DEC/1 (14 November 2001) para 28.

38 Margaret A Young, 'Fragmentation or Interaction: The WTO, Fisheries Subsidies, and International Law' (2009) 8 World Trade Review 477, doi.org/10.1017/s1474745609990140. For the latest draft working text for a new agreement, see WTO Doc TN/RL/W274R5 (Working Documents, 26 July 2018).

39 For estimates of global losses, see David J Agnew et al, 'Estimating the Worldwide Extent of Illegal Fishing' (2009) 4(2) PLoS ONE e4570, doi.org/10.1371/journal.pone.0004570.

40 The estimated annual value of IUU fish harvested or transhipped in the region is around US\$616.11 million: Duncan Souter et al, Towards the Quantification of Illegal, Unreported and Unregulated (IUU) Fishing in the Pacific Islands Region (Report, MRAG Asia Pacific, February 2016) i. 41 The growth in illegal fishing is even thought to have spurred the European migration crisis: 'Illicit Migration to Europe: Consequences of Illegal Fishing and Overfishing in West Africa', The Global Initiative Against Transnational Organized Crime (Web Page, 8 May 2015) <www.globalinitiative.net/ illicit-migration-to-europe-consequences-of-illegal-fishing-and-overfishing-in-west-africa/>. 


\section{Emerging Powers and the South China Sea}

Deborah Cass revealed much about how international law was seen to be facilitating political intrigue and legal wrangling. This has become most apparent since, in the context of the dispute over the South China Sea brought by the Philippines against China. The EEZ concept had itself spurred already existing expansionist tendencies within the South China Sea, the region comprising the western Pacific Ocean spanning an area of almost 3.5 million square kilometres to the south of China, to the west of the Philippines, to the east of Vietnam and to the north of Malaysia, Brunei, Singapore and Indonesia. ${ }^{42}$ At the end of the Cold War, these countries (as well as Taiwan) sought title to sovereignty over the islands in order to take advantage of the 200-nautical-mile zone and its security and economic benefits. Christopher Joyner wrote:

Were all claimants to declare exclusive economic zones or continental shelf delimitations seaward from points fixed by islands over which they now assert sovereignty, nearly the entire ocean and sea-bed in the South China Sea would be subjected to various degrees of national jurisdiction. An ocean region legally comprised of high seas and international sea-bed would be rendered into a semi-enclosed sea. ${ }^{43}$

The hope of Joyner was that China would agree to dispute settlement and that the claimant states would find solutions based on regional cooperation and joint resource development.

When Philippines sought arbitration against China pursuant to Part XV of UNCLOS in 2013, China neither accepted nor participated in the proceedings. The tribunal found that it had jurisdiction in $2015 .{ }^{44}$ China consistently rejected the Philippines' recourse to arbitration, ${ }^{45}$ which

\footnotetext{
42 South China Sea Award (n 4) [3].

43 Christopher C Joyner, 'The Spratly Islands Dispute: Rethinking the Interplay of Law, Diplomacy, and Geo-politics in the South China Sea' (1998) 13 International Journal of Marine and Coastal Law 193, 199, doi.org/10.1163/15718089820491980, footnotes omitted.

44 In the Matter of the South China Sea Arbitration before an Arbitral Tribunal constituted under Annex VII to the 1982 United Nations Convention on the Law of the Sea (Philippines $v$ China) (Award on Jurisdiction and Admissibility) (Permanent Court of Arbitration, Case No 2013-19, 29 October 2015) ('Award on Jurisdiction and Admissibility').

45 South China Sea Award (n 4) [11].
} 
was conducted at the Permanent Court of Arbitration in the Hague. ${ }^{46}$ The tribunal gave its substantive findings in the absence of Chinese counsel or submissions, although it sought to ascertain China's position via public statements and it noted that its responsibility was to satisfy itself 'not only that it has jurisdiction over the dispute but also that the claim is well founded in fact and law..$^{47}$

While the case most notoriously centred on disputes between the Philippines and China regarding the legal basis of maritime rights and entitlements in the South China Sea (and especially the status of certain geographic features artificially constructed by China), it also related to the lawfulness of certain actions taken by China within a part of the South China Sea that constituted the Philippines' EEZ. As such, the tribunal made a number of findings relating to the interpretation of UNCLOS and art 56. The tribunal's reasons are discussed in the following section but for the purposes of the present part it is sufficient to note that the rise in economic might of one maritime nation did not prevent the tribunal from ruling in favour of the coastal state: the Philippines' sovereign rights in its EEZ were upheld.

In addition to engaging in emerging sovereign claims, Deborah Cass may be said to have foretold current narratives of a clandestine takeover of sovereign control through access and investment arrangements, especially in the South Pacific. Almost three decades after her article documented reports of the Soviets getting a 'new Pacific toehold', a news report was headed 'Kiribati Deal Shocks Fishing World' ${ }^{48}$ The narrative was familiar, but the proponents had changed: Kiribati had decided against granting fishing rights to US boats and instead granted rights to a higher bidder: this time, China and Taiwan. An industry leader was quoted as saying, '[w]ith this China is now taking over the South Pacific and there will be no sustainability: this will rip the guts out of the American tuna fleet'. ${ }^{49}$

46 The Tribunal found that there was a dispute within the terms of UNCLOS art 288, and that resolution of the dispute would not require an implicit determination of sovereignty (which would have been outside of the jurisdiction of UNCLOS). The Tribunal noted it was 'fully conscious of the limits on the Claims submitted to it and, to the extent that it reaches the merits of any of the Philippines' Submissions, intends to ensure that its decision neither advances nor detracts from either Party's claims to land sovereignty in the South China Sea': Award on Jurisdiction and Admissibility (n 44) [153].

47 South China Sea Award (n 4) [12]. In addition to the Philippines legal team, observers to the proceedings included Australia, the Republic of Indonesia, Japan, Malaysia, Singapore, the Kingdom of Thailand and the Socialist Republic of Viet Nam: see para 15.

48 Michael Field, 'Kiribati Deal Shocks Fishing World' Stuff(Web Page, 10 October 2014) <http:// www.stuff.co.nz/business/industries/10603447/Kiribati-deal-shocks-fishing-world>.

49 Ibid. 
The sentiments have similarities with a commonly heard narrative of an Asian takeover of Australian assets. When a proposed investment by China and Chinese investors into Australia's energy infrastructure was blocked by the Australian treasurer in 2016, the reason given was national security. ${ }^{50}$ The law of the sea emerged as a key concern. Alongside cyber hacking, some commentators linked the Australian decision to Chinese military actions in the South China Sea. ${ }^{51}$ Australia's alliance with the US was a dominant theme, especially in the context of the US's support for the Philippines' initiation of the arbitration leading to the South China Sea Award.

In summary, Deborah Cass's keen observations of changing sovereign power structures could be replicated today, notwithstanding the rotating roles of some of the main protagonists. The US and China are asserting their global status (and differences) via oceans policy, focusing on military, strategic and fishing concerns. While regional disputes over the South China Sea existed well before UNCLOS III, the recent practices of China in asserting its rights and power - including through land reclamations - have been documented by the arbitral tribunal constituted under UNCLOS Annex VII. Meanwhile, Australia's aid to the South Pacific faces competition from China, the US, Europe and Japan - and much of the aid from these latter countries is linked expressly or impliedly with fisheries. The retreat of Soviet fleets in the Pacific is now over, with a newly empowered Russia seeking influence in fisheries and security. ${ }^{52}$ Even among drastic geopolitical change since the publication of Deborah Cass's article in 1987, her insight of a quiet revolution over fishing rights (for her, in a bipolar Cold War environment) continues to apply in the multipolar expansions that are undergirded by global capitalism.

50 See former Australian treasurer Scott Morrison, '[The foreign investment review process] has not enabled us to identify suitable mitigations to protect against the national security issues in this case': Paul Karp, 'Scott Morrison Blocks Ausgrid Sale on National Security Grounds', The Guardian (online, 11 August 2016) <https://www.theguardian.com/australia-news/2016/aug/11/scott-morrison-blocksausgrid-sale-on-national-security-grounds $>$.

51 See Peter Jennings of the Australian Strategic Policy Institute cited in: 'China Ramps Up Pressure over Blocked Ausgrid Bid', SBS News (online, 18 August 2016) <http://www.sbs.com.au/news/ article/2016/08/18/china-ramps-pressure-over-blocked-ausgrid-bid>.

52 Olga Krasnyak, 'Russia Vying for Power in the South Pacific', The Vanuatu Independent (online, 22 November 2017) <http://web.archive.org/web/20181203092156/https://vanuatuindependent. com/2017/11/22/russia-vying-for-power-in-the-south-pacific/s. 


\section{Article 56 and the Discretion of Coastal States}

One of the preoccupations of Deborah Cass's analysis was the relative power and discretion of the coastal states granted by the new EEZ provisions in Part V of UNCLOS. The legal provisions achieved a shift in economic and geopolitical interests by allocating sovereign rights and duties and setting out specific grounds for cooperation and the granting of access. At the time of Deborah Cass's article, important questions were unanswered about the common intentions of the parties and the wording they adopted. Her arguments relating to these provisions have proved remarkably accurate, as this part demonstrates.

\section{Interpreting Art 56}

The legal provision at the heart of the newly entrenched EEZ regime is art 56 of UNCLOS, which sets out the rights, jurisdiction and duties of the coastal state in the EEZ. It provides:

\section{Article 56}

1. In the exclusive economic zone, the coastal State has:

(a) sovereign rights for the purpose of exploring and exploiting, conserving and managing the natural resources, whether living or non-living, of the waters superjacent to the seabed and of the seabed and its subsoil, and with regard to other activities for the economic exploitation and exploration of the zone, such as the production of energy from the water, currents and winds;

(b) jurisdiction as provided for in the relevant provisions of this Convention with regard to:

(i) the establishment and use of artificial islands, installations and structures;

(ii) marine scientific research;

(iii) the protection and preservation of the marine environment;

(c) other rights and duties provided for in this Convention. 
2. In exercising its rights and performing its duties under this Convention in the exclusive economic zone, the coastal State shall have due regard to the rights and duties of other States and shall act in a manner compatible with the provisions of this Convention.

3. The rights set out in this article with respect to the seabed and subsoil shall be exercised in accordance with Part VI.

The rights and duties of other states in the EEZ are set out in art 58; these are limited to freedoms of navigation and overflight and the laying of submarine cables and pipelines, 'and other internationally lawful uses of the sea related to those freedoms, such as those associated with the operation of ships, aircraft and submarine cables'. In art 62, the states 'whose nationals have habitually fished in the zone' are mentioned in the context of coastal states that lack the capacity to harvest the entire allowable catch within their EEZ. States aside from the coastal states may vie for access so as to fish for the surplus. In granting access, the coastal states are expected to take into account 'the need to minimize economic dislocation in States whose nationals have habitually fished in the zone or which have made substantial efforts in research and identification of stocks', in addition to the needs of developing countries, the overarching need to conserve living resources and other factors. ${ }^{53}$

The question that was occupying many commentators at the conclusion of UNCLOS III was whether this allocation of sovereign rights would lead coastal states to exclude all foreign fishing. The question of access to fishing zones had implications economically, politically and ideologically, as set out in the first part of this chapter. Daniel O'Connell, for example, was concerned that by granting sovereign rights to coastal states, UNCLOS marks the 'triumph of individualism over collectivism' ${ }^{54}$ Lawrence Juda was warning of the 'creeping jurisdiction' of the EEZ, ${ }^{55}$ an issue that continues to be a 'siren song'. 56

53 UNCLOS (n 6) arts 61-62.

54 Daniel P O'Connell, The International Law of the Sea, ed IA Shearer (Oxford University Press, 1982) vol 1, 552, cited in Cass, 'The Quiet Revolution' (n 5) 96.

55 Lawrence Juda, 'The Exclusive Economic Zone: Compatibility of National Claims and the UN Convention on the Law of the Sea' (1986) 16 Ocean Development and International Law 44, doi.org/ 10.1080/00908328609545784, cited in Cass, 'The Quiet Revolution' (n 5) 84.

56 See, eg, Bernard Oxman, 'The Territorial Temptation: A Siren Song at Sea' (2006) 100 American Journal of International Law 830. 
Deborah Cass was rightly preoccupied by ambiguities in the text. She stated:

It is not at all clear what 'due regard' means in this context. Does it mean that the coastal state must take into account the interests of other states or is it just a mechanism to encourage discussion between the parties in the event of a conflict? ${ }^{37}$

She concluded, '[i]t is likely to be the latter, given the wide-ranging scope of coastal state authority defined by article $56{ }^{\prime}{ }^{58}$

This conclusion is the position reached by the recent arbitral tribunal in the South China Sea dispute. China had asserted jurisdiction over maritime areas of the South China Sea encompassed by the so-called 'nine-dash line', due in part to 'historic rights'. The Philippines submitted that these claims were contrary to UNCLOS and without lawful effect (the case did not extend to sovereignty claims, which would have been outside of the jurisdiction of the tribunal). The tribunal accepted the Philippines' arguments, concluding that UNCLOS superseded any historic rights or other sovereign rights or jurisdiction in excess of the limits imposed therein. ${ }^{59}$ The tribunal reasoned: ${ }^{60}$

As a matter of the text alone, the Tribunal considers that the Convention is clear in according sovereign rights to the living and non-living resources of the exclusive economic zone to the coastal State alone. The notion of sovereign rights over living and non-living resources is generally incompatible with another State having historic rights to the same resources, in particular if such historic rights are considered exclusive, as China's claim to historic rights appears to be. Furthermore, the Tribunal considers that, as a matter of ordinary interpretation, the (a) express inclusion of an article setting out the rights of other States and (b) attention given to the rights of other States in the allocation of any excess catch preclude the possibility that the Convention intended for other States to have rights in the exclusive economic zone in excess of those specified.

57 Cass, 'The Quiet Revolution' (n 5) 88.

58 Ibid.

59 South China Sea Award (n 4) [278].

60 Ibid [243]. 
The tribunal further found that China had breached art 56 with respect to the Philippines' sovereign rights by promulgating a moratorium on fishing in the South China Sea (which it had done in 2012 without exception for the Philippines' EEZ and without limiting the moratorium to Chinese flagged vessels). ${ }^{61}$ China was found to have breached art 58 by failing to prevent its nationals from unlawfully fishing in the EEZ. ${ }^{62}$ China was also found to have violated other UNCLOS provisions, including inter alia those related to the protection and preservation of the marine environment, and requirements to 'protect and preserve rare or fragile ecosystems as well as the habitat of depleted, threatened or endangered species and other forms of marine life' ${ }^{63}$

The decision in the South China Sea Award came after an ITLOS decision which upheld certain contingent rights of coastal states in assuming regulatory competence over bunkering activities of foreign vessels operating near their EEZ. ${ }^{64}$ The decision, which related to the arrest by a coastal state of a vessel that was providing fuel for fishing vessels within the EEZ, included the following statement, in a passage that is consistent with Deborah Cass's reading of art 56:

The term 'sovereign rights' in the view of the Tribunal encompasses all rights necessary for and connected with the exploration, exploitation, conservation and management of the natural resources, including the right to take the necessary enforcement measures. ${ }^{65}$

\section{Institutional Aspects}

Aside from interpreting the treaty text, there are other reasons for Deborah Cass's conclusion of a wholesale power of coastal states in deciding on questions of access to their EEZs. At least part of her argument seems to be based on a nuanced appreciation of the institutional aspects of the law of the sea regime. Decisions on coastal state access are not part of the compulsory dispute settlement system that is otherwise a hallmark

61 Ibid [716]

62 Ibid [757].

63 Ibid [992].

$64 M / V^{\prime}$ 'Virginia G' (Panama/Guinea-Bissau) (Judgment) (2014) ITLOS Rep 4.

65 Ibid, para 211. 
of UNCLOS and its far-reaching Part XV. ${ }^{66}$ The discretion of states to decide whether or not to give access to other states to their surplus fisheries is not open to conflict resolution, and Deborah Cass argues that this increases the likelihood that coastal states will have total discretion in access matters. I see this insight to be a precursor to her analysis, almost two decades later, of the way in which the compulsory dispute settlement system of the World Trade Organization has affected the substance of trade norms. Even in this early piece she recognises that international laws are shaped by their institutional context: here, in the EEZ regime, the lack of an enforceable provision means that the power is left to the discretionholding state; there, the compulsory dispute settlement of the WTO means that discretionary trade liberalisation rules have been interpreted to contain procedural and substantive obligations that are not written in the text. The special place occupied by the WTO Appellate Body, due partly to the ex ante consent to its jurisdiction by WTO members, means it was the perfect candidate for Deborah Cass's masterful treatment in her book, The Constitutionalization of the World Trade Organization, which features in another chapter in this collection. ${ }^{67}$

Deborah Cass's arguments contrast heavily with the reception that UNCLOS received from other quarters: for Philip Allott, for example, the revolution of UNCLOS was of quite a different kind. Allott celebrates the diminishing concepts of territorial exclusivity within the Convention, demonstrated primarily but not solely in the entrenchment of the ideal of 'common heritage of mankind' in Part XI. ${ }^{68} \mathrm{He}$ compares changes in notions of exclusive political control over land territory (especially given international society's direct interest in all that happens within state systems, manifested, for example, by human rights law) and predicts that '[p] reconceptions of exclusive political control over naturally communal sea areas must tend to become anomalous to the same extent' ${ }^{69}$ He also celebrates the requirement that disputes over access to EEZs should be resolved

66 UNCLOS (n 6) art 297(3). On limits to the compulsory dispute settlement system of UNCLOS, see generally Natalie Klein, Dispute Settlement in the UN Convention on the Law of the Sea (Cambridge University Press, 2005).

67 Kerry Rittich, 'Deborah Cass, The Constitutionalization of the World Trade Organization: A Reading in Time', this volume.

68 Allott, 'Mare Nostrum' (n 23) 785.

69 Ibid 768. 
on the basis of equity and in the light of all the relevant circumstances, taking into account the respective importance of the interests involved to the parties as well as to the international community as a whole. ${ }^{70}$

For Allott, this clause was intended to construct a social process where contracting parties would be required to achieve, 'in their future interactive social behaviour, equal treatment, equitable sharing, regard for legitimate interests ... effective protection for the marine environment', and so on. ${ }^{71}$ Allott writes:

[E]very sea area, whatever its conceptual articulation in terms of property relations, is conceived in [UNCLOS] as being, not incidentally but inherently, an area of power and interest shared by two or more state systems. The exercise of the supposed property right is, in all cases, actually a process of decision making within procedural and substantive constraints. ${ }^{72}$

Deborah Cass is right that the lack of compulsory dispute settlement might eviscerate the processes that Allott saw so idealistically, and yet after 30 years we have seen legal issues of the EEZ regime litigated by a number of parties at different tribunals, including via advisory opinions. While these have confirmed that coastal states have sole discretion on questions of access - as exemplified by the South China Sea arbitral award - they have also provided a stronger sense of the obligations to 'give due regard to the needs of other states'. International law contains procedural duties of states to be 'other-regarding' in their decisions, as I argue below. Recent cases have also shown that the holders of discretion under the EEZ regime are not always the weaker party in traditional power relations, and that the risk of overexploitation of resources within the EEZ by the holders of sovereign rights - the coastal states - should not go unchecked.

70 UNCLOS (n 6) art 59.

71 Allott, 'Mare Nostrum' (n 23) 785.

72 Ibid 785. 


\section{'Due Regard', 'Due Diligence', and the 'Duty to Cooperate'}

Experience, new law, state practice and changing ideas in international law have led to a richer sense of rights and duties, in the context of fisheries and beyond. Although there has not been a direct challenge to the allocation of access according to the EEZ regime (in accordance with Deborah Cass's expectations), there have been a number of disputes that have applied UNCLOS art 56 directly or indirectly. Moreover, decisions from the International Court of Justice (ICJ), ITLOS and other tribunals serve to demonstrate the duties of coastal states, while new laws for straddling fish stocks ${ }^{73}$ and lawmaking for areas beyond national jurisdiction ${ }^{74}$ impose broader duties on all states. This part examines the jurisprudence and situates it within broader normative developments in international law.

\section{The Duties of Coastal States}

A challenge to the designation by a coastal state of a marine protected area (MPA) provides new perspectives on Deborah Cass's thesis on unfettered coastal state discretions. In 2010, the UK, as part of its asserted sovereignty over the British Indian Ocean Territory, established an MPA within the EEZ of the Chagos Archipelago. Mauritius, the long-suffering former colony and neighbour, had relied on access to the relevant EEZ for fishing and economic interests, and challenged the UK using the dispute settlement provisions of UNCLOS. An arbitral tribunal constituted under Annex VII of UNCLOS handed down its decision in $2015 .{ }^{75}$ Its claim was in part a claim about the substance of art 56: whether the UK should have had 'due regard' to the interests of Mauritius in deciding on the MPA.

73 See especially Fish Stocks Agreement (n 29) and accompanying text; see also Rosemary Rayfuse, 'The United Nations Agreement on Straddling and Highly Migratory Fish Stocks as an Objective Regime: A Case of Wishful Thinking?' (1999) 20 Australian Year Book of International Law 253.

74 Margaret A Young and Andrew Friedman, 'Biodiversity Beyond National Jurisdiction: Regimes and Their Interaction' (2018) 112 AJIL Unbound 123, doi.org/10.1017/aju.2018.47.

75 Chagos Marine Protected Area Arbitration (Mauritiusv United Kingdom) (Award) (Permanent Court of Arbitration, Case No 2011-03,18 March 2015) ('Chagos'), see further: <https://pca-cpa.org/en/ cases/11>. The members of the Tribunal were Ivan Shearer, Christopher Greenwood, Albert Hoffmann, James Kateka and Rüdiger Wolfrum. 
The UK sought to give a restrictive meaning to its obligations, submitting that "the meaning of "due regard" in art 56 does not mean to give effect to the rights of other States' ${ }^{76}$ The UK also stated that its public consultations with Mauritius had satisfied the relevant obligations.

The tribunal declined to find 'any universal rule of conduct' in the obligation to give 'due regard', but drawing on the ordinary meaning of the terms found that the obligation required the UK to have 'such regard for the rights of Mauritius as is called for by the circumstances and by the nature of those rights'. ${ }^{77}$ The degree of 'due regard' was high given the significant effect that the establishment of the MPA would have on Mauritius's rights. ${ }^{78}$ After reviewing the UK's efforts at consultation, the tribunal found that it did not have sufficient 'due regard', ${ }^{79}$ and concluded that the proclamation of the MPA was incompatible with UNCLOS. ${ }^{80}$

The joint dissenting and concurring opinion of Judges Wolfrum and Kateka give additional content to the standard required of 'due regard'. The judges expressed doubts that the UK had not acted under an ulterior motive in establishing the MPA, and found that it violated the standard of good faith. ${ }^{81}$ Citing the Nuclear Tests Case, ${ }^{82}$ they emphasised that ' $\left[\mathrm{t}\right.$ ] rust and confidence are inherent in international co-operation'. ${ }^{83}$ The implications of the case are wide-ranging, both for the question of marine environmental protection, ${ }^{84}$ and for the ongoing quest by Mauritius to set right historic failures of the UK during the decolonisation process, which was considered by the ICJ in its Advisory Opinion in 2019. ${ }^{85}$

\footnotetext{
76 Chagos (n 75) [458].

77 Ibid [519].

78 Ibid [521].

79 Ibid [524].

80 Ibid [536].

81 Chagos (n 75) [90] (Judges Wolfrum and Kateka).

82 Nuclear Tests (Australia v France) (Judgment) [1974] ICJ Rep 253, 269 [46].

83 Chagos (n 75) [90] (Judges Wolfrum and Kateka).

84 David Ong, 'Implications of the Chagos Marine Protected Area Arbitral Tribunal Award for the Balance Between Natural Environmental Protection and Traditional Maritime Freedoms' in Stephen Allen and Chris Monaghan (eds), Fifty Years of the British Indian Ocean Territory: Legal Perspectives (Sprinter, 2018) 263, doi.org/10.1007/978-3-319-78541-7_11.

85 Legal Consequences of the Separation of the Chagos Archipelago from Mauritius in 1965 (Advisory Opinion) [2019] ICJ Rep 95. This opinion was delivered after the completion of the writing of the present chapter and is not considered further here.
} 
The content of coastal states' duties was given separate consideration by ITLOS in one of its first advisory opinions. ${ }^{86}$ The request for an advisory opinion was brought by Cape Verde, Gambia, Guinea, GuineaBissau, Mauritania, Senegal and Sierra Leone, acting as the 'Subregional Fisheries Commission', to determine the context of legal responsibilities to take necessary measures to prevent, deter and eliminate IUU fishing. The tribunal reviewed the emphasis given in UNCLOS to the coastal states' management of natural resources (art 56(1)) and their role in determining the allowable catch (art 61), allocating any surplus (art 62) and enforcing domestic laws to meet their obligations. In the light of these 'special rights and responsibilities given to the coastal states', the primary duty to take measures with respect to IUU fishing was found to rest with coastal states. ${ }^{87}$

These primary responsibilities did not release other states from obligations, however. ${ }^{88}$ Flag states, or those that license or register the vessels fishing in the relevant zones, had to have duties 'to take the necessary measures to ensure that their nationals and vessels flying their flag are not engaged in IUU fishing activities'. ${ }^{89}$ The tribunal noted:

[T] he obligation of a flag State ... to ensure that vessels flying its flag are not involved in IUU fishing is also an obligation 'of conduct'... as an obligation 'of conduct' this is a 'due diligence obligation', not an obligation 'of result' ... The flag State is under the 'due diligence obligation' to take all necessary measures to ensure compliance and to prevent IUU fishing by fishing vessels flying its flag. ${ }^{90}$

These comments were cited with approval in the South China Sea Award, ${ }^{91}$ and were used to ground that tribunal's conclusions that China had failed to exercise due diligence in preventing fishing by Chinese flagged vessels

86 Request for an Advisory Opinion Submitted by the Sub-Regional Fisheries Commission (SRFC) (Advisory Opinion) (International Tribunal for the Law of the Sea, Case No 21, 2 April 2015) ('SRFC request'), archived at <http://perma.cc/KY5V-EMXP>.

87 Ibid [106].

88 Ibid [108].

89 Ibid [124]. The tribunal noted that its findings were restricted to flag states that were not members of the relevant cooperative convention: [89].

90 Ibid [129]. For further exposition of the due diligence concept, see Pulp Mills on the River Uruguay (Argentina v Uruguay) [2010] ICJ Rep 425 [187] ('Pulp Mill'); Responsibilities and Obligations of States Sponsoring Persons and Entities with Respect to Activities in the Area (Advisory Opinion) (International Tribunal for the Law of the Sea, Case No 17, 1 February 2011) 10 ('Responsibilities and Obligations of States').

91 South China Sea Award (n 4) [744]. 
in various locations in the South China Sea, and thus failed to exhibit due regard for the Philippines' sovereign rights with respect to fisheries in its EEZ. Accordingly, China was found to have breached its obligations under art 58(3) of the Convention. ${ }^{92}$

The tribunal in South China Sea also quoted the oft-cited passage from Mox Plant that 'the duty to cooperate is a fundamental principle in the prevention of pollution of the marine environment under Part XII of the Convention and general international law'. ${ }^{93}$ This was important for its finding that China had, through its toleration and protection of, and failure to prevent, Chinese fishing vessels engaging in harmful harvesting activities of endangered species, breached arts 192 and 194(5) of the Convention. ${ }^{94}$

A 'duty to cooperate' was also important for the reasoning of the ICJ in Whaling in the Antarctic, when Japan was found to have breached its obligations under the Whaling Convention. ${ }^{95}$ As is well known, the Court agreed with Australia that Japan failed to meet the appropriate standard of conduct required of parties to the Whaling Convention when undertaking scientific research into whaling. A key deficiency in Japan's conduct was its failure to give due regard to decisions of the International Whaling Commission (IWC).

The Court's articulation of a duty of states to cooperate with the IWC can be traced to the terms of the Whaling Convention ${ }^{96}$ itself, and the reporting and monitoring functions of the IWC. Judge ad hoc Charlesworth also observed that the concept of a duty of cooperation is the foundation of legal regimes dealing (inter alia) with shared resources and with the environment'. ${ }^{97}$ As I have argued elsewhere, ${ }^{98}$ the ICJ judgment is heavy with consequences for the future conduct of states, and for the ability of tribunals to allow for evolution of the law in applying treaties. While the Court refused to take an overt 'evolutionary' interpretation of the Whaling Convention, it established a duty to give reasons when states

\footnotetext{
92 Ibid [757].

93 MOX Plant (Ireland v United Kingdom) (Provisional Measures) (2001) ITLOS Rep 89, para 82.

94 South China Sea Award (n 4) [992].

95 Whaling in the Antarctic (Australia v Japan: New Zealand Intervening) (Judgment) (International Court of Justice, General List No 148, 31 March 2014) ('Whaling in the Antarctic').

96 International Convention for the Regulation of Whaling, opened for signature 2 December 1946, 161 UNTS 74 (entered into force 10 November 1948) art VIII.

97 Whaling in the Antarctic (n 95) [13] (Judge Charlesworth).

98 See generally Margaret A Young and Sebastián Rioseco Sullivan, 'Evolution Through the Duty to Cooperate: Implications of the Whaling Case at the International Court of Justice' (2015) 16 Melbourne Journal of International Law 310.
} 
divert from established practices, even if those practices are not binding. ${ }^{99}$ A reviewable obligation of states parties to 'give due regard' is likely to lead to a more responsive and adaptive system of law, and a different conception of sovereignty and responsibility. ${ }^{100}$

\section{'Due Regard' in Public International Law and the Needs of Conservation}

Quite aside from these recent cases, one could argue that the seeds for a fuller conception of an obligation to give 'due regard' were sown much earlier, predating UNCLOS III and the precise wording of art 56. In the Fisheries Jurisdiction Case of 1974 (between Iceland and Germany), the ICJ held that:

It is one of the advances in maritime international law, resulting from the intensification of fishing, that the former laissez-faire treatment of the living resources of the sea in the high seas has been replaced by a recognition of a duty to have due regard to the rights of other States and the needs of conservation for the benefit of all. ${ }^{101}$

In addition to this jurisprudence, we see an embrace of concepts such as duties of cooperation across a vast range of scholarship. Indeed, we are now familiar with the preoccupation of reason-giving and procedural obligations that scholars of global administrative law such as Benedict Kingsbury, Richard Stewart and Nico Krisch would advance. ${ }^{102}$ There are at least some similarities with the work of Elinor Ostrom, who found that the tragedy of the commons could be averted by cooperative systems rather than enclosure. ${ }^{103}$ Localised, cooperative accounts of monitoring

99 Ibid 318. Even though Japan had voted against key resolutions of the IWC, it was required to 'give due regard' to those resolutions, including in providing adequate justification for its scientific methodologies and practices.

100 Ibid.

101 Fisheries Jurisdiction (Germany v Iceland) (Judgment) [1973] ICJ Rep 49 [64]. Rather than dwell on this case, Deborah Cass prefers to rely on the earlier Fisheries Jurisdiction case between Iceland and the UK, which was important in recognising the concept of coastal states possessing 'preferential rights' in the fishing zones adjacent to their coasts; 'Application Instituting Proceedings', Fisheries Jurisdiction (United Kingdom v Iceland) [1972] ICJ Pleadings 1. She may have passed over the Court's comments here due to their focus on the high seas.

102 Benedict Kingsbury, Nico Krisch and Richard B Stewart, 'The Emergence of Global Administrative Law' (2005) 68 Law and Contemporary Problems 15.

103 Elinor Ostrom, Governing the Commons: The Evolution of Institutions for Collective Action (Cambridge University Press, 1990), doi.org/10.1007/978-3-531-90400-9_93. See further Margaret A Young, 'International Adjudication and the Commons' (2019) 41 University of Hawai i Law Review 353. 
and peer review also feature in the New Governance literature of Joanne Scott, among others. ${ }^{104}$ Reporting and review mechanisms have become established in new multilateral agreements, including the Paris Agreement, as well as human rights regimes. To return to fisheries, the poor conservation and management record of coastal states has led to direct calls for the institution of these types of mechanisms. ${ }^{105}$

Some would go even further; writing in 2013, Eyal Benvenisti provides a Rawlsian account of states as trustees of humanity. ${ }^{106}$ Benvenisti argues that international law contains obligations for states to 'take other-regarding considerations seriously into account in formulating and implementing policies, even absent specific treaty obligations'. ${ }^{107}$ Benvenisti argues:

The sovereign as trustee must ensure meaningful opportunities to have the voices of affected stakeholders - both foreign governments and individuals - heard and considered, and must offer them reasons for its policy choices. ${ }^{108}$

These normative arguments have parallels, once again, in the fisheries context. The public trust doctrine has been argued as the appropriate legal concept to apply to the EEZ. ${ }^{109}$ Moreover, the duty to cooperate has been emphasised to apply to the fishing states who participate within regional fisheries management organisations as well as to new entrants seeking access to fishing areas, ${ }^{110}$ with distributional and ecological consequences that have not yet been satisfactorily resolved in fisheries.

104 Gráinne de Búrca and Joanne Scott (eds), Law and New Governance in the EU and US (Hart Publishing, 2006).

105 Richard Barnes, 'The Convention on the Law of the Sea: An Effective Framework for Domestic Fisheries Conservation' in David Freestone, Richard Barnes and David M Ong (eds), The Law of the Sea: Progress and Prospects (Oxford University Press, 2006) 233, 259-60, doi.org/10.1093/ acprof:oso/9780199299614.003.0013.

106 Eyal Benvenisti, 'Sovereigns as Trustees of Humanity: On the Accountability of States to Foreign Stakeholders' (2013) 107 American Journal of International Law 295, 318, doi.org/10.5305/ amerjintelaw.107.2.0295.

107 Ibid 300.

108 Ibid 318.

109 Mary Turnipseed et al, 'The Silver Anniversary of the United States' Exclusive Economic Zone: Twenty-Five Years of Ocean Use and Abuse, and the Possibility of a Blue Water Public Trust Doctrine' (2009) 36 Ecology Law Quarterly 1.

110 Andrew Serdy, 'Pacta Tertiis and Regional Fisheries Management Mechanisms: The IUU Fishing Concept as an Illegitimate Short-Cut to a Legitimate Goal' (2018) 48 Ocean Development and International Law 345, doi.org/10.1080/00908320.2017.1349525. 
Deborah Cass was more reticent about the content of states' duties to have regard to others in international law. While she recognised conservation imperatives, she also noted that many of the smaller developing states would not have capacity to determine issues such as the effect of their actions on ecosystems. ${ }^{111}$ She considered the obligation of coastal states to take into account the effects of fishing on associated and dependent species to be 'probably not enforceable'. ${ }^{112}$ The final section of this chapter seeks to account for the scepticism she exhibited in the context of fisheries access, and demonstrates that the issues continue to be important for the future of the law of the sea.

\section{Inbuilt Restrictions on Sovereignty Over Natural Resources}

Deborah Cass's argument that coastal states have total discretion in deciding upon access to their fishing zones might be said to be underpinned by a regard for the developing states whose interests were so central to the advancement of the EEZ concept. ${ }^{113}$ She was advocating for justice and an equitable allocation that would enable those weaker states to finally have some control over their economic future under globalisation. Deborah Cass's work at the time as research assistant to the Commission of Inquiry into the Rehabilitation of Nauru might have contributed to this perspective. ${ }^{114}$ Indeed, it is difficult not to have sympathy for the argument, especially when historically many of those states had ensured sustainable fishing within their region, as opposed to the rapacious attitudes of the distant water fishing nations. Yet Deborah Cass perhaps was too accommodating in her belief that the sovereign equality of states could serve to equalise an international legal order that, after years of war and colonialism, had given rise to this very system of developing countries. Third World approaches to international law would

111 Cass, 'The Quiet Revolution' (n 5) 92, writing in the context of the coastal state's determination of the maximum sustainable yield and its need to take into account associated and dependent species, see UNCLOS (n 6) art 61.

112 Cass, 'The Quiet Revolution' (n 5) 92.

113 See Nandan, 'The Exclusive Economic Zone' (n 15).

114 See Anthony Anghie in this volume: Tony Anghie, 'Self-Determination and Beyond: Reflections on the Aftermath of the Nauru Case'. 
subsequently show a different side to these issues. ${ }^{115}$ Deborah Cass herself was perhaps aware of the need for caution in drawing conclusions about the Pacific nations, stating upfront that her analysis was not conclusive given the lack of primary material available. She observed that the island states 'do not possess the kind of bureaucracies to which we are accustomed to produce the data required'. ${ }^{116}$

Thirty years after UNCLOS III, we now know that enclosure of the EEZ has not led to sustainability. The responsibility for this must rest with coastal states, alongside other states and actors. The idea that coastal states are the best stewards for their total allowable catch has not been supported by state practice since the EEZ concept was codified, with many domestic fisheries in a deplorable state. ${ }^{117}$ Many states are unable to monitor or police their areas of EEZ, leading to a burgeoning and organised criminal focus on illegal fishing. Fishing activities that follow agreed access rights within EEZs can be appallingly exploitative and unsustainable. In return for financial assistance, trade concessions and aid programs, the small coastal states surrounded by vast areas of the ocean have allowed vessels to wreak havoc on their resources: to cite just one set of examples, early access agreements with the EU led to adverse effects on the sustainability of Senegal's coastal fisheries. ${ }^{118}$ In part, the collapse of many domestic fisheries lies with deficiencies within UNCLOS's EEZ framework, and an absence of more direct and coherent obligations on coastal states. ${ }^{119}$

In her review of UNCLOS Part V, Deborah Cass was perhaps too restrictive in her analysis of the content of coastal states' obligations to give 'due regard'. In addition to the obligation of the coastal state to ensure that the maintenance of living resources in the EEZ is not endangered by overexploitation, ${ }^{120}$ there are general environmental obligations with respect to pollution, rare and fragile ecosystems and the habitat of threatened species, both in the high seas and within the EEZ to which she may have referred, and which have progressed since the publication of her

115 Ibid. See also in this volume, Kerry Rittich, 'Deborah Cass, The Constitutionalization of the World Trade Organization: A Reading in Time'; Deborah Cass, 'Navigating the Newstream: Recent Critical Scholarship in International Law' (1996) 65 Nordic Journal of International Law 341, doi.org/ 10.1163/15718109620294924; see further below n 128.

116 Cass, 'The Quiet Revolution' (n 5) 85.

117 Barnes, 'An Effective Framework' (n 105) 233.

118 Witbooi, 'The Infusion of Sustainability' (n 32) 674.

119 Barnes, 'An Effective Framework' (n 105).

120 UNCLOS (n 6) art 61(2). 
article. ${ }^{121}$ Tribunals have given increased attention to concepts such as the 'duty to cooperate' and the need to undertake 'due diligence', ${ }^{122}$ and these concepts pertain not just to coastal states but to flag states and others. UNCLOS has evolved, aided especially by the proliferation of a range of instruments from within and outside the law of the sea that have helped to give content to emerging notions. ${ }^{123}$ This evolution in obligations, as well as rights, is essential if international law is to address modern environmental challenges, especially those like climate change that are both caused and manifested outside of bounded areas such as EEZs. ${ }^{124}$

It should be remembered, too, that it is often the powerful states who hold coastal rights, rather than the developing states - a fact that Deborah Cass also acknowledged. ${ }^{125}$ In the Chagos arbitration, the issue was not whether the holders of sovereign rights in the EEZ could enjoy discretion in selling off the resources, but whether the rich state could enjoy discretion in closing the zone. As discussed above, two of the judges were extremely concerned by the behaviour of the rights-holder in denying access: they saw in the UK's conduct a continual disregard of Mauritius's rights carried on from colonial times. In contrast, the South China Sea case involved questions about an emerging economic power: China, which had hitherto been on the side of the developing countries, ${ }^{126}$ and was now seeking unlawful access to the weaker state's EEZ.

Perhaps instead of idealism about coastal states, Deborah Cass's views are underpinned by a deep scepticism about the potential, and even appropriateness, of international law in giving content to duties and obligations. As we have heard in the context of international criminal law, ${ }^{127}$ one needs to ask what international society needs to be to host

121 See especially UNCLOS (n 6) art 192, 'States have the obligation to protect and preserve the marine environment'. See also South China Sea Award (n 4) [945].

122 See Pulp Mills (n 90) [187]; Responsibilities and Obligations of States (n 90) 10.

123 Alan Boyle, 'Further Development of the Law of the Sea Convention: Mechanisms for Change' (2005) 54 International and Comparative Law Quarterly 54, doi.org/10.1093/iclq/lei018. See also Irina Buga, 'Between Stability and Change in the Law of the Sea Convention: Subsequent Practice, Treaty Modification and Regime Interaction' in Donald R Rothwell et al (eds), The Oxford Handbook of the Law of the Sea (Oxford University Press, 2015) 46, doi.org/10.1093/law/9780198715481.003.0003. 124 For reflection on the territorially bounded notions of duties in the face of global warming, see Joanne Scott, 'The Geographical Scope of the EU's Climate Responsibilities' (2015) 17 Cambridge Yearbook of European Legal Studies 1, doi.org/10.1017/cel.2015.4.

125 Cass, ‘The Quiet Revolution' (n 5) 90.

126 China's position during the UNCLOS III negotiations 'as one of the foremost defenders of the rights of developing States' was remarked upon by the Tribunal in the South China Sea dispute, see South China Sea Award (n 4) [251].

127 See Gerry Simpson in this volume, 'Concluding Remarks'. 
a form of law: for Simpson, retributive justice might not yet enjoy its needed social foundation, while for Deborah Cass, normative content to the duties with respect to the EEZs was not justified. It might be that Deborah Cass held greater confidence in the scope of domestic law to provide the necessary content to ethical, cultural, social or environmental obligations. Her critique of the notion of obligations of coastal states under international law may indeed have sustained her interest in domestic constitutional law and her academic pursuits demonstrated that the two disciplinary fields have never been anything but closely intertwined.

The answer to the question posed by Deborah Cass's expansive interpretation of the rights of coastal states perhaps comes from Deborah Cass herself, writing 10 years after 'Quiet Revolution' was published. When engaging with a range of critical legal theories and methods in 1996, she suggested some potential research projects that would ensure such theories and methods could be deployed usefully, to effect lasting transformation after international law's repeated injustices. She posed as one example the examination of:

[W] hether there are inbuilt restrictions upon the application of [the] principle of permanent sovereignty over natural resources and, if there are, whether these internal limits ought to be reassessed in the light of current understandings of equality and disadvantage. ${ }^{128}$

International law has demonstrated that it is possible to place restrictions over the principle of coastal states' sovereign rights to their EEZ. The obligations of 'due regard' and 'due diligence' are examples of such restrictions. Arguably the Chagos arbitration has signalled a preparedness of international tribunals to take into account equality and disadvantage in developing these norms, at least in the joint dissenting and concurring opinion. Perhaps it is this set of issues that will require the next revolution.

\section{Conclusion}

This chapter has considered the revolutionary aspects of the entrenchment of an exclusive economic zone in the United Nations Convention on the Law of the Sea. It shows that Deborah Cass's insights about the high stakes

128 Cass, 'Navigating the Newstream' (n 115). 
of the maritime zones - which covered contested territory including the EEZ, the high seas and the deep seabed mining area - have continued relevance, even as some of the early defenders of the rights of developing states have now assumed the role of traditional maritime powers.

For Deborah Cass in 1987, the quiet revolution of UNCLOS lay in the empowerment of coastal island states against the exploitative and destructive tendencies of the distant water fishing nations and their constructed ideological battles. Over 30 years later, her political, legal and critical insights continue to push international lawyers, enriching our understanding, practice and tools for change. Her core argument - that the newly entrenched EEZ regime provided total discretion to coastal states with respect to which states would access the resources - has been vindicated. In the South China Sea Award, for example, China's historic rights were found to have been extinguished by the creation of the EEZ regime in UNCLOS, meaning that the Philippines is free to decide upon issues of access and control with respect to its EEZ. Yet there are other issues that cannot be separated from the issue of the rights of coastal states: these relate to the duties of coastal states to give 'due regard' to the needs of others and to practice due diligence. This has become a major preoccupation, and tribunals have found in the law of the sea an evolving set of duties since the publication of Deborah Cass's analysis.

The law of the sea is a precursor to much of the evolution and development of public international law. Deborah Cass's preoccupation with the content and institutional structure of art 56's requirement for states to give due regard to the interests of others demonstrates broader tensions in the substance, procedure and even idea of international law. Her interest in the position of developing states in the Pacific reminds us to be cautious about the institutional capacities and technical resources some states have in exercising their rights. Her work also suggests that the discharge of duties of coastal states needs to acknowledge historical inequality and disadvantage in order to be just. Cooperative arrangements rest on this substantive engagement as well as the procedural guarantees developed by treaties and jurisprudence. An awareness of the broader ideological and geopolitical aspects of these issues necessarily complicates a neat division between community and exclusivity in public international law. 
This text is taken from Traversing the Divide: Honouring Deborah Cass's Contributions to Public and International Law, edited by Kim Rubenstein, published 2021 by ANU Press, The Australian National University,

Canberra, Australia.

doi.org/10.22459/TD.2021.05 